\title{
as the First Official Łódź-Based Literary Group
}

\section{The history of the creation of the poetic journal and the 'Meteor' group}

When in 1918 Poland regained independence after more than 100 years of partitions, new conditions emerged which fostered the development of the Polish culture and literature, which was particularly visible in Warsaw, Kraków, Lviv, and Poznań. Łódź, however, stayed behind during the interwar period. To quote from Literatura Łodzi w ciagu jej istnienia. Szkic literacki $i$ antologia by Ludwik Stolarzewicz, a chronicler of urban literary life and a promoter of academic and cultural activities:

it is the second most populated city in Poland - and one of the last ones... in terms of its literary and academic life. ${ }^{1}$

The author of the compendium explained the situation by saying that:

Łódź has never been a city which drew the literary folk offering them acceptable material and cultural conditions. In fact, it is located too close to Warsaw, which for the "people of letters" has always constitutes an object of longing and strive.

That is why no one will ever stay in Łódź for good. ${ }^{2}$

1 L. Stolarzewicz, Literatura Łodzi w ciagu jej istnienia. Szkic literacki i antologia, Łódź [no publisher information], p. 51. [Unless indicated otherwise, quotations and titles in English were translated from Polish].

2 Ibid., p. 7. 
The chronicler thus concluded his pessimism-riddled argument: "There are few Łódź inhabitants who have remained faithful to their family town." ${ }^{3}$ Ludwik Stolarzewicz's position was shared a few decades later by Elżbieta Pleszkun-Olejniczakowa, a researcher of Łódź's interwar literature, who - in the article titled Kulturowy rozwój Łodzi w okresie międzywojennym - argued that:

Łódź did produce in the interwar period any outstanding creators. I omitted creators who despite being born in Łódź, created outside it; otherwise one should list first of all Julian Tuwim, who was born in Łódź but whose output was fairly unrelated to the city of his birth, though he did receive from his family town Łódźs Literary Award, or Meteors, i.e. poets who had attended Łódź middle schools but who wrote their poetry in Warsaw... ${ }^{4}$

However, I believe it is worth studying closer the biographies and artistic activities of those 'Meteors', who were the originators of presumably the first (and - mainly for that reason - significant) literary group in the Łódź area. Despite living in Warsaw, at the verge of their writing careers, they eagerly used Łódź as the leading motif in texts they published in Czasopismo Poetyckie Meteor and beyond, describing it as an example of an industrial city and the city of a major revolution.

The founders of 'Meteor' first met in the building of the Municipal Men's Middle School in Eódź (today: Tadeusz Kościuszko High School no. $3^{5}$ ), which they all attended in the years 1925-1926. Marian Piechal' ${ }^{6}$, Grzegorz Timofiejew ${ }^{7}$, and Kazimierz Sowiński ${ }^{8}$ - captivated by literature - made themselves their first literary attempts, which sometimes proved successful, e.g. Marian Piechal, still as a middle schooler, decided to write Przed

3 Ibid.

${ }^{4}$ E. Pleszkun-Olejniczakowa, Kulturowy rozwój Łodzi, “Acta Universitatis Lodziensis. Folia Litteraria Polonica" 2015, no. 3(29), p. 7.

${ }^{5}$ In the years 1891-1916, the school - where Russian was the language of instruction was called the Governmental Men's Middle School in Łódź. It was founded by Karol Scheibler. Between 1904 and 1914 it was attended by Julian Tuwim. In 1905, the school's pupils engaged in an effort to introduce Polish as the language of instruction at all schools.

${ }^{6}$ (1905-1989) - a Polish poet, essayist, and translator, co-founder of the Meteor literary group (he published his works under the pseudonym Wiesław Drzewicz), and from 1929 to 1931 a member of the Warsaw-based Kwadryga group. In 1929, his début collection of poems, Krzyk z miasta, was published, and in 1930 he published Rozmowy o pacyfizmie - a collection of interviews with Władysław Broniewski, Paweł Hulka-Laskowski, Antoni Słonimski, and Józef Wittlin. Vide: Współczesna Łódź literacka. Słownik Autorów, ed. T. Błażejewski, Łódź 1989, pp. $94-97$.

7 (1908-1962) - a Polish poet, writer, and translator, co-founder of the Meteor literary group (1928), the editor of the Prady periodical (1930-1931) and the Wymiary periodical (19381939) as well as of the underground Biuletyn Kujawski bulletin. Vide: ibid., pp. 121-122.

${ }^{8}$ (1907-1982) - a Polish poet, writer, and an author of dramas. In 1921-1928 he attended the Governmental Men's Middle School in Łódź. Already then, he was a co-editor of the Almanach Literacki school gazette. He débuted with his poems in the Głos Poranny journal. He then published in the Meteor literary monthly, published by a literary group with the same name. The group published one collection of the poet's poems, titled Gwiazdy na strychu. Many of the poems within the volume raised the topic of the harsh living conditions of Łódź labourers. After Meteor was dissolved in 1930, he continued his activities by publishing in the Prądy periodical. Władysław Broniewski, in: Współcześni polscy pisarze i badacze literatury. Słownik Bibliograficzny, eds. J. Czachowska, A. Szałagan, Warsaw 1994, vol. 1, pp. 281-287. 
pomnikiem Adama Mickiewicza w Warszawie 9 , in which he employed a crafty composition of the sonnet. That early work of his was published in the fifth issue of a Warsaw-based periodical, Biesiada, in $1924^{10}$.

Grzegorz Gazda, the author of Stownik europejskich kierunków i grup literackich XX wieku, indicated the year 1928 as the start of the operations of the Meteor literary group. In February, the first issue of Czasopismo Poetyckie Meteor was released in Warsaw by dint of the efforts of the group's originators. Such a form of publication of the achievements of poets was typical of literary groups which operated in the interwar period. A similar history applied to the popular at that time Skamander group, whose members used to publish in the periodical which carried the same name, or the Awangarda Krakowska group, whose poets would publish in Zwrotnica. The fact of running own periodical guaranteed the artists easier access to readers as well as it very often enabled emerging poets to début in the literary market.

Czasopismo Poetyckie Meteor, which was the complete name developed by Grzegorz Timofiejew, Marian Piechal, and Kazimierz Sowiński, was supposed to be a monthly, yet only three issues were published, which have survived in fragments to this day. Bolesław Kaczorowski, the publisher, did stipulate the option to order a quarterly, semi-annual or annual subscription (a piece of information included in the masthead).

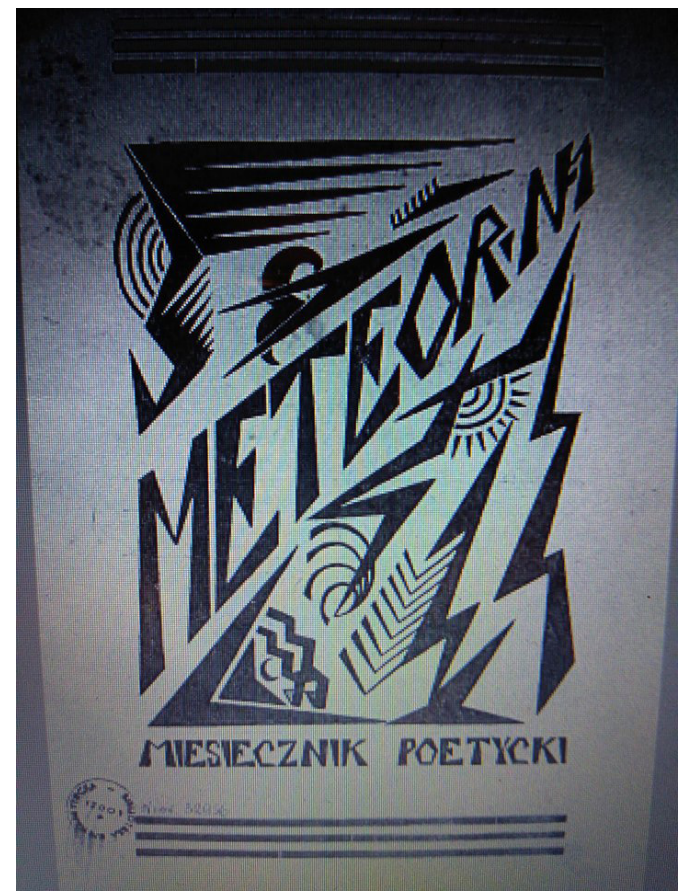

Cover of the first issue of Czasopismo Poetyckie Meteor ${ }^{11}$.

\footnotetext{
${ }^{9}$ Marian Piechal, ibid., vol. 6, pp. 284-287.

10 Ibid.

11 Czasopismo Poetyckie Meteor 1928, issue 1.
} 
That indicates that it was expected to become successful, that the texts by meteors would become popular, and that young poets would supply it with material for new issues, which sadly did not happen. The ephemeral nature of the group and the journal was hidden in the very name, which can be further confirmed by the cover of the first issue designed by Paulina Halpernówna. Following the contemporary trend, she proposed a geometric composition which utilised the symbols of the Moon and the Sun surmounted by a hand-drawn title of the journal Meteor, which should be associated with astronomical terminology: a meteor is a bright trace left by a meteoroid rushing through the Earth's atmosphere. It is probable that the founders of 'Meteor' intended to leave a similar trace with their works.

\section{The Meteors' programme}

The idea to start the Meteor literary group was not only triggered by the desire to début or promote own poetry among Łódź readers. Meteors also intended to practise their literary skills using new avant-garde methods and ideas, eagerly adopted from the Russian empire at the beginning of the 20th century and not - as one might assume - from Western European capitals. Grzegorz Gazda thus described the phenomenon:

Therefore, despite many dynamic contacts with the Western culture maintained mostly by painters (Tadeusz Peiper's Spanish experiences are worth mentioning at this point), the first concepts, innovative ideas and avant-garde strategies were basically adopted through Russian inspiration. Also, because, mind you, a considerable portion of Polish lands, including Warsaw and Łódź, was up to 1918 Russian partition and Russian was the official language there. ${ }^{12}$

What must be said, though, is that members of 'Meteor' were particularly close to the attitudes of the representatives of futurism, which developed on the foundation of a rebellion against the traditional approach to painting, architecture, and literature. Both Meteors and the representatives of the Italian trend felt a strong need to influence - using sometimes minor works of literature - the perception of the existing systems and state institutions, which should be exerted by the society. That device typical of authors of the 1920s was raised by Tomasz Cieślak in the text titled Bóg i niebo w poezji rewolucyjnej dwudziestolecia międzywojennego:

The community trying to transfer onto the Polish soil a pro-reading model of revolutionary poetry, particularly the Nowa Kultura, made efforts to establish a cooperation with futurist authors not so much due to their innovative devices, but due to their negative approach to traditions and historical heritage, the slogans of social and artistic progress they professed, and the

${ }_{12}$ G. Gazda, Rosyjskie inspiracje polskiej awangardy. Vide: https://digilib.phil.muni.cz/ bitstream/handle/11222.digilib/132613/LitterariaHumanitas_012-2003 1_17.pdf?sequence=1, [accessed: 20 January 2019]. 
cult of activism, violence and war, all close to the revolutionary attitude. The clearly leftist world view choices by Polish futurists were also significant. ${ }^{13}$

The closeness of the socialist state had a direct influence on the shape of the Polish proletarian poetry. In the early 1920s, the Worker Culture Association of Cultural and Education Organisations was formed; it reflected the principles of the Soviet Proletkult. Its main goal was to create "a culture of the masses"14. Since that moment on, proletariat poetry was marked by the cult of a collective hero and a disdain for past literature. Fervent debates were held over those postulates by the representatives of evolutionist arts across the pages of 1920s periodicals, e.g. Robotnik, Głos Literacki, Lewy Tor, and Wiadomości Literackie. That was also the path which the founders of Czasopismo Poetyckie Meteor followed..$^{15}$

The first issue of Meteor, published in February 1928, began with a collective two-page Editorial, in which the groups' guiding principles were formulated. In the introduction, the authors referred to the age-long human struggle to "grasp the inner-most experience and cast it into words" 16 , which is the only carrier of truth.

The originators of the first Łódź-based literary group presented themselves in the first words directed to the readers of Meteor as fierce proponents of lofty form, sophistical rhymes, beauty in words, and compositional precision and clarity. They noticed the ever-valid value of classical poetry and they wished to save it from being forgotten, boldly stating their readiness to "pick up the banner of Pure Art which has fallen out of the stiffening hands of the last survivors"17. The recent middle schoolers defended ferociously humanistic values, aesthetics, and the norms of classical beauty, which were all contested by the events of the recent war. They assured that:

We view the mission of art in eternal beauty and eternal truth and we shall not allow for it to be tarnished by some foul tendencies. We hereby raise the banner of healthy Poetry. ${ }^{18}$

History and tradition, according to the founders of Meteor, was supposed to be the force supporting new battles for "a new workday, agricultural reform, health fund, and a dictatorship of the proletariat"19. Words were supposed to be the most efficient means of expressing the grandness of the academic and technical progress, the industrialisation of cities, the development of industry to a scale previously unknown, and the emergence of a new society and a new working class.

${ }^{13}$ T. Cieślak, Bóg $i$ niebo w poezji rewolucyjnej dwudziestolecia międzywojennego, "Acta Universitatis Lodziensis. Folia Litteraria Polonica" 2001, no. 4, p. 75.

14 A.Z. Makowiecki, Kultura Robotnicza, [in:] Literatura polska, przewodnik encyklopedyczny, vol. 1, Warsaw 1984, pp. 27-28.

${ }_{15}$ Z. Barański, Rosyjska literatura radziecka, [in:] Dzieje literatur europejskich, vol. 3, Warsaw 1989, p. 259.

16 Od Redakcji, “Czasopismo Poetyckie Meteor” 1928, issue 1, pp. 3-4.

17 Ibid., p. 3.

18 Ibid., p. 4.

19 Ibid. 
The thoughts and discussions of the theoreticians of the Meteor poetic group on the function and value of words and of poetry culminated in the development of the so-called 'constructive metaphorism', which was employed as the artistic programme of their literary community. In the final fragment of the foreword, they addressed the readers in the following manner:

May the stretched-out aerials of Your nerves accept every sound of the inspired words! Open the closed shutters of Your eyelids to the path of true Poetry, Poetry with a "broad breath", within the horizon of which there appears the Constructive Metaphorism as one of Its first and morning starts. ${ }^{20}$

Within this concept, poems were supposed to focus on chains of uniform metaphors or on a single metaphor. Its task was to bind poetic works which should "talk life". The fact of selecting this particular rhetoric figure out of all resulted from the fascination which Timofiejew, Piechal, and Sowiński shared with the works by the artists of Awangarda Krakowska, for whom the metaphor was a path for expressing and creating a new poetic reality.

Another text - similarly important for the formation of the Meteor's programme - was one by Władysław Bieńkowski ${ }^{21}$, titled Na barykady and published in the second issue of the periodical. It directly referred to one of the most important events in the history of interwar literature, i.e. the 1925 publication of the Trzy salwy poetic bulletin, which was the joint effort of Władysław Broniewski ${ }^{22}$, Stanisław Ryszard Stande ${ }^{23}$, and Witold Wandurski ${ }^{24}$, who:

while stirring artistic rebellion were also thinking about radical social and ideological changes. They were developing their leftist attitude

20 Ibid.

${ }^{21}$ (1906-1991) - a Polish commentator, sociologist, and politician, from 1930 to 1936 a member of the 'Życie' Socialist Youth Organisation and the Young Communist League of Poland. During the Second World War he was an editor of underground periodicals: Głos Warszawy, Literatura Walczaca, and Przełom. Trybuna Wolności, and a member of the Central Editorial Board of the Polish Workers' Party. Władysław Bieńkowski, in: Współcześni polscy pisarze..., vol. 1, pp. 265-267.

22 (1897-1962) - a Polish poet, representative of revolutionary poetry, translator; a soldier of the Polish Legions, participated in the Polish-Soviet War. In 1925, together with Stanisław Stande and Witold Wandurski, he published Trzy salwy - the first Polish manifesto of proletarian poets. His poetry was strongly bound with his biography and fortunes, and the history of the Polish nation and of the activists of the labour movement; it possessed visible revolutionary and patriotic undertones. Władysław Broniewski, ibid., Warsaw 1994, vol. 1, pp. 281-287.

${ }_{23}$ (1897-1937) - a Polish poet, translator, and an activist of the Communist Party of Poland; he collaborated with the Nowa Kultura and the Kultura Robotnicza, an official body of the Communist Worker Party of Poland. He also collaborated with the Dźwignia monthly. In 1925, together with Władysław Broniewski, with whom he became friends, he organised a semi-legal Warsaw Worker Theatre (later: Worker Theatre Studio), which operated until 1931. Stanisław Ryszard Stande, ibid., Warsaw 1994, vol. 7, pp. 433-434.

${ }^{24}$ (1891-1934) - a Polish dramatist, poet, commentator, director, political activist, and cultural-education activist; in 1916-1919 he studied law in Russia, he lectured at the Free Art University and was a director and the manager of an amateur theatre in Kharkiv. After returning to Poland, he was the manager of a theatre in Łódź. He was an activist of the Communist Worker Party of Poland and the KPP. He collaborated with Nowa Kultura as well as Kultura Robotnicza. Witold Wandurski, ibid., Warsaw 1994, vol. 9, pp. 26-29. 
precisely in admiration of the 1917 revolution and its class outcomes in Russia. ${ }^{25}$

As the three poets stated in the foreword to the poetic collection:

We are not writing about ourselves. We are the labourers of words. We need to express that which other people of the trade cannot express. In proletariat's ruthless fight with bourgeoisie, we stand firmly to the left of the barricade. Anger, faith in victory and joy (joy in the fight) require us to write. May our words rumble like cannons through the streets of the centre, may they echo in factory districts. We are fighting for a new social order. This fight is the core of our works. ${ }^{26}$

Similarly to the authors of Trzy salwy, the members of 'Meteor' considered the poet as a person who helps workers express their postulates and their deep discontent with the continuing class divisions.

In the first words of the manifesto, Władysław Bieńkowski indicated the double personality of contemporary poetry which, on the one hand, postulated the proletariat's fierce struggle with bourgeoisie and, on the other, proposed falling back on the Romantic tradition and - in following it - presenting personal dilemmas of the author within a moody atmosphere. Thus, the commentator suggested that readers should conduct an experiment:

Look closely at the other side of the barricade! If you could do a vertical cross-section of a contemporary creator, you would be struck by the lack of any mental association between one surface, existing absolutely, approach to phenomena of a social nature and the domain of aesthetic sensations, various feelings, and general personal experiences, so to speak. ${ }^{27}$

The two-element structure of poetry was also discussed by Władysław Broniewski in the poem titled Poezja, included in the already mentioned Trzy salwy. The poet devoted the first stanza to poetry maintained within the Romantic spirit, which he defined as follows:

Ty przychodzisz jak noc majowa, biała noc, uśpiona w jaśminie, i jaśminem pachną twoje słowa, i księżycem sen srebrny płynie, (...) szepcesz sny, szepcesz słowa tajemne, w słowach cichych skąpana jak w deszczu...

\author{
You come as a May night, \\ white night, asleep in jasmine, \\ and your words smell of jasmine, \\ and the silver dream flows with the \\ moon, (...) \\ you whisper dreams, \\ you whisper mysterious words, \\ in quiet words soaked like in the rain...
}

${ }^{25}$ G. Gazda, Rosyjskie inspiracje polskiej awangardy, [in:] Literaria Humanitas, Brno 2003, pp. 167-165.

${ }^{26}$ W. Broniewski, S.R. Stande, W. Wandurski, Trzy salwy: biuletyn poetycki, Warsaw 1925, p. 5.

27 W. Bieńkowski, Na Barykady, “Czasopismo Poetyckie Meteor” 1928, issue 1, p. 33. 
Po czym wreszcie w strofie czwartej jasno stwierdza, że:

Nam te słowa ciche nie starczą.

Marne słowa. I błahe. I zimne.

Ty masz werbel nam zagrać do marszu!

Smagać słowem! Bić pieśnią!

Wznieść hymnem!
Finally, in the fourth stanza, he clearly stated that:

For us, those quiet words are not enough.

Feeble words. And trivial. And cold.

You are supposed to snare drum us to march!

Lash with words! Hit with songs! Lift with hymns!

In the above-quoted poem, the author clearly referred to the Romantic tradition, according to which a poet's task was to spur the nation to fight, give courage, and ensure eternal glory for the heroes of the events. In the time of growing social conflicts, i.e. dictatorships and class struggles, Broniewski wished to use poetry mainly for revolutionary purposes as it could not remain contrary to the reality in which the society was fully immersed.

In his essay, Władysław Bieńkowski attempted to define proletariat poetry, its essence and function. Therefore, he somewhat ironically referred several times to Paweł Hulka-Laskowski ${ }^{28}$, a writer and a representative of worker poetry, who saw value in money as the only factor which defined affiliation to a social class. The fact of having money became - according to "Mr Laskowski" (as Bieńkowski referred to him) - the basic criterion which differentiated the proletariat from the bourgeoisie. He criticised Pawel Hulka-Laskowski's position by stating that:

With his mind fixed on the ideology of "becoming brothers", Mr Laskowski creates a townsman/Ford social theory clearly leading to a situation when if someone is a proletarian, that is his own fault and to correct it he should strive to become richer. Away with the old social and economic truths! The world is an idyll where anyone can or even should become a Rockefeller. ${ }^{29}$

The third and final issue of Czasopismo Poetyckie Meteor included another text of a manifesto character, i.e. Mitologja czynu. Here, Władysław Bieńkowski offered a severe account of both authors and readers of literature in terms of their willingness to act. To that end, he used the Romantic and the Young Poland traditions, i.e. periods when artists incessantly called for actions and fight only to suddenly lose that accumulated energy and justify social passivity, which, as the author noted, became convenient as when:

28 (1881-1946) - a Polish writer and translator; activist and commentator. He was born in Żyrardów in a working-class family as the son of Józef Hulka and Elżbieta née Howorko, workers of a textile factory, a Protestant family of the Czech origins. Paweł Hulka-Laskowski in: Współcześni polscy pisarze..., Warsaw 1994, vol. 3, pp. 284-287.

${ }^{29}$ W. Bieńkowski, ibid. 
we found ourselves in a situation in which the internal eagerness for action found an unobstructed exit, when there vanished those bonds with which we justified our indifference, which, I am not afraid to say this, we nurtured to have a ready-made excuse for our attitudes - in that moment we started to realise that that long-accumulated energy devoured itself, that our strength was false. We learnt that between a belief in actions, between a sense of strength for its application and the action itself there is a major mental link which have just faded in us. ${ }^{30}$

In the second part of his argument, Bieńkowski commented in critical terms on the lack of a programme, the lack of an action plan, and the asocial attitude being promoted by the poets of the Warsaw-based Skamander poetic group. That reference was justified as Skamandrites, who were seemingly the proponents of a simple joyful life, considered poets as people who could shape their own individual visions of the world, and whose works had an exceptional influence on the society.

\section{The worker dimension of Meteors' poetry}

The works of the Meteor poets - published in the poetic journal in 1928 and later in the weekly literary supplement to Głos Polski - were not uniform in terms of ideology; on the contrary, they were extremely individualised. Apart from the most eagerly raised proletariat and social topics related to the Łódź community, there also appeared those which took the form of musings on personal issues and existential matters.

However, in order to fully describe the works by Meteors, one must begin with works which belonged to worker poetry, which was used most often as it constituted a weapon in the struggle against the ruling bourgeoisie. In the first issue of the journal which united the Łódź-based literary group, there appeared a poem by Kazimierz Sowiński, titled Pająk fabryczny ${ }^{31}$ :

Dzień jest szary w słoneczne, niespokojne plamy,

kradzione z nieba siatką zakurzonych okien.

Czas się zwija na kłębki nicią bawełnianą:

co godzina powolnym odnosisz je krokiem.

Aż jedna chwila zadrży przeraźliwym świstem,

zatrzyma cię i przerwie twój marsz niestrudzony. -
The day is grey with sunny relentless spots,

stolen from the sky with a net of dusty windows.

Time bundles up with a cotton thread:

every hour you carry them moving slowly.

When suddenly one moment will shake with terrible wizz,

it will stop you and interrupt your tireless march. -

30 W. Bieńkowski, Mitologja czynu, “Czasopismo Poetyckie Meteor” 1928, issue 3, pp. 49-53.

31 K. Sowiński, Pająk fabryczny, “Czasopismo Poetyckie Meteor” 1928, issue 2, p. 30. 
Wachlarz drzew się na czole chłodnym rozłoży liściem,

po żyłach się rozejdzie spokój pracy skończonej.

O, wróć prędko do Sali kierować nici pasmem

biegiem transmisji liczyć ostatnie

nim wieczór czerwonym murem zdusi turkot maszyn,

słowo redukcja słońce zegarem twym uczyni.

I wówczas wszystkie nici, jakieś w życiu wysnuł, szmatami pajęczyny wyjrzą z brudnych kątów.

Długie nogi pająka do oczu ci się wcisną,

by wśliznąć się do mózgu i myśli poplątać.

Czarna ci noc otworzy wszystkie drogi świata,

byś poszedł pierwszą lepszą i zapomniał krzywdy,

ale miasto-selfaktor nićmi je posplata w węzeł twardy, jak rozpacz. Nie rozplączesz go nigdy.

A hand fan of trees will spread in a cool leaf on your forehead, and the peace of finished work will spread through the veins.

Oh, come back soon to the Room to guide threads in a line

with the course of transmission count the final hours:

until the evening deadens the rumble of machines with a red wall,

the word reduction will turn the sun into your clock.

And then all the threads which you have spun throughout your life, will peer with cobweb rags from dirty corners.

The spider's long legs will push into your eyes,

to slide into your brain and tangle your thoughts.

Black night will open all the world's roads for you,

so you could follow whichever and forget harm,

but the city-spinning machine will bind them with threads

into a knot hard as despair. You will never untangle it.

The poem was directly addressed to an employee of one of the cotton-processing factories, which operated at that time. The typical Łódź labourer, bent over a ball of cotton, is presented as a slave to the job, counting their time by observing the result of the endlessly repeated activity, i.e. finished wound-up balls, which the poet indicated in the first stanza:

Czas się zwija na kłębki nicią bawełnianą,

co godzina powolnym odnosisz je krokiem. (...)

Wachlarz drzew się na czole chłodnym rozłoży liściem,

po żyłach się rozejdzie spokój pracy skończonej.
Time bundles up with a cotton thread,

every hour you carry them moving slowly. (...)

A hand fan of trees will spread in a cool leaf on your forehead, and the peace of finished work will spread through the veins. 
Kazimierz Sowiński compared the poem's addressee to a spider, whose only task, and one which he desires, is to spin threads. That bold and essentially negative comparison deprived the labourer of the ability to think - and of power - and it depicted their passivity and inability to act. The factory spider, who was the addressee of the words written by one of the founders of the Meteor group, was part of the worker collective: deprived of individualism, living in a "spinning machine town", from which, as the final line indicates, there is no escaping.

Then, in the third issue (December 1928), the author included a poem titled Wigilja ${ }^{32}$, which - similarly to the previous one - constituted a special depiction of the monotonous and predictable life of the factory proletariat:

Już niedługo się skończy godzina najkrwawsza

i fabryka westchnieniem otworzy ci drzwi,

ostatnią ci godzinę wyturkocze warsztat

i rozwiąże uwagę $\mathrm{w}$ dwa sznurki szarych brwi.

Rozplątany kłąb myśli potoczy się bezładnie

torem podmiejskich ulic, potem polnych dróg -

do wiatru jak do dzbana ustami przypadniesz,

by wargi ci otrzeźwił jego mroźny chłód.

Pan Bóg - Dobry Gospodarz cichutko zapali

w górze na Mlecznej Drodze tysiąc gwiezdnych świec,

ażebyś, wśród zasp śnieżnych powoli stąpając,

mógł lepiej swych zmęczonych, chorych kroków strzec.

lecz cię znużenie ciężko na ziemi położy,

gdzieś na pustem rozstaju zabłąkanych dróg...
Soon the bloodiest hour will end and the factory will open the door for you with a sigh,

the workshop will rumble the last hour

and will untie attention into two strings of eyebrows.

The untangled ball of thoughts will roll inertly

down suburban street, then rural roads -

you will fall into wind like with your

lips on a bottle,

so its chill could sober up your lips.

Good Lord - the Good Host will quietly light

up in the sky in the Milky Way a thousand starry candles, so that you could stomp slowly through snow drifts, so you could better protect your tired sick steps.

but weariness will put you hard to the ground, somewhere at the crossroads of some forsaken roads... 
nagle oczy w ździwieniu szeroko otworzysz:

głód cię szybko zaniesie za rodzony próg.

Igły świerku zapachną i gwiazd

świeczki zadrżą,

rogal księżyca wyjrzy z za obrusa chmur -

sięgniesz i czarną dłonią rozłamiesz go twardo,

ale nie przełkniesz, bo nie będziesz mógł.

Potem wszystko zasypią białe śniegu płatki,

do syta ich naniesie sinym ustom wiatr:

to Pan Bóg będzie z Tobą dzielił się opłatkiem -

ty dasz Mu wśród modlitwy opłatki swych warg. suddenly you will open your eyes in surprise:

hunger will quickly carry you past your family threshold.

Spruce needles will smell and the candles of the stars with shiver, the crescent moon will peer from behind the tablecloth of clouds you will reach out and break it hard with your black hand,

but you will not swallow as you won't be able to.

Then everything will become covered with the white flakes of snow, the wind will bring until satiety for the bluish mouth:

it will be the Lord who will break with You the wafer -

you will give Him surrounded by prayers the wafers of your lips.

Kazimierz Sowiński noticed that the labourers lost all their accumulated strength and energy at their workplace. Paradoxically, only there, surrounded by noise and rumble, could they focus and harness their thoughts in order to perform their "work" well:

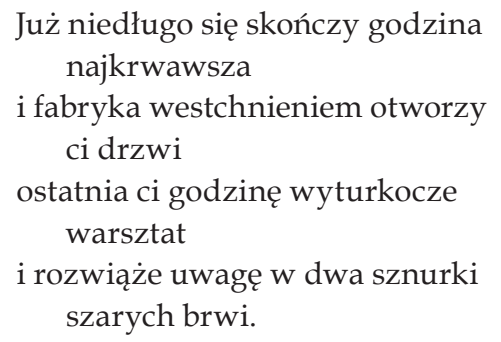

Soon the bloodiest hour will end and the factory will open the door for you with a sigh the workshop will rumble the last hour and will untie attention into two strings of eyebrows.

In his work, the poet did not omit the question of the consequences of the factory drudgery. The tiredness and weariness which accompanied labourers prevented them from noticing even the highest values. In the third stanza, the author mentioned God, an element which played a special role in proletarian poetry. God was often held accountable for the exploitation of the working class, which was indicated by, among others, Aleksander Wat. ${ }^{33}$ Yet, Kazimierz Sowiński placed God in the role of the good Host, suggesting that the society also possessed many experiences associated with the 
rule of a bad host, i.e. the oppressor. The Lord was attributed with a whole array of positive qualities. He was charitable, merciful, empathetic, and he showed people ways which they should follow. That device was a metaphor of a road leading to a social revolt. Christ appeared in the text as an ally of the proletariat, a leader of the impending revolution. Any doubts as to how labourers perceived God in the pre-revolutionary depiction were dissipated in the final line, in which the author inserted the motif of breaking a wafer. The breaking occurred symbolically; a person who often doubted the existence of the Lord and his good intentions reconciled with Him.

A similar view of worker existence was offered by Włodzimierz Słobodnik ${ }^{34}$ in Praca $^{35}$ :

Prężą się, tężą gumy muskułów.

Nabrzmiewa bryłą siły opiłą

Przegięty tułów.

Ośmiogodzinnej pracy kowadło Iskrami sekund pryska i lśni.

Młoty roboty druzgoczą kadłub

Tępych, ospałych, leniwych dni!

Buch! - młotem w lewo - ! buch! młotem w prawo!

Złoty miód potu namaszcza skronie.

Sława robocie! Potowi sława!

Sława zgrubiałej, chropawej dłoni!
Muscular rubber flexes and hardens.

Swells drunken with the power of form

The bent back.

The anvil of the eight-hour workday

Sputters and glistens with sparks of seconds.

Labour hammers shatter the hull

Of blunt, sluggish, lazy days!

Poof! - hammer to the left - ! poof! hammer to the right!

The golden money of sweat anoints the brow.

Hail to work! And hail to sweat!

Hail the callous course hand!

The author focused on the appearance of a tired worker who stays in endless motion as well as on the disgraceful conditions in which he spends eight hours a day, as that was the daily work norm achieved during the Łódź Revolution of 1905. The clatter of anvils and hammers, and the roar of machinery could be heard all around; the scene was dominated by the sight of muscles flexed to the extreme, sweat flowing down people's foreheads, and the unnatural position assumed by labourers to prove the slogans: "Hail to work! And hail to sweat!/ Hail the callous course hand!"36

${ }^{34}$ (1900-1991) - a Polish poet of Jewish descent; translator of French, Russian, and Soviet literatures; satirist, author of children's books. He studied Polish at the University of Warsaw. In 1921, he made his poetic début in the Pam-Bam futurist pamphlet. During the interwar period he was a member of the Kwadryga literary group. Włodzimierz Słobodnik, in: Wspótcześni polscy pisarze..., Warsaw 1994, vol. 7, pp. 329-332.

${ }^{35}$ W. Słobodnik, Praca, "Czasopismo Poetyckie Meteor" 1928, issue 1, p. 16.

${ }^{36}$ W. Słobodnik, ibid. 
Labour aristocracy grew wealthier and more powerful through the extreme exploitation of proletarians sentenced to factory drudgery which considerably exceeded human physical endurance, as was indicated by Grzegorz Timofiejew in the poem titled O koniu, który tęskni ${ }^{37}$ :

Miasto urąga o świcie, kiedy woźnica cię pogna,

Przez przymknięte powieki okiennic patrzą szyderczo okna.

Obsiadły cię oczy niedobre, jak gdyby muchy natrętne...

O, przyjacielu - koniu, jak smutno wleczesz się stępa!

Płoty szczerzą się do Ciebie sztachet spróchniałe zęby

I plują śliną zieloną - liściastą zielenią dębów.

Aż cię policjant na rogu ruchem pałeczki wgmatwa

W sznury jadących powozów, w supły, tworzone przez auta.

W koleje twojego cierpienia, tnącem zębami godzin,

Jak zagubioną podkowę zostawiasz na bruku młodości.

Dopiero gdy zmierzch ci posypie gwiazd pozłocisty owies,

Wracasz zmęczony do stajni spocząć na miękkiej słomie.

W źdźbła śpiewające wsłuchany niespokojnie, dawne wspomnienie...

O łąkach śnisz słodko zielnych.

- wspominasz dawne wspomnienie...

Gdy ślepia twe noc jak kobyła grzywą ciemności przysłoni,

Czujesz się źrebcem małym w zielonej kołysce błoni.
The city reviles at dawn, when the carter rushes you,

Through closed eyelids of shutters windows peer sneeringly.

Ill eyes are set on you, as if some persistent flies...

Oh, my friend - horse, you drag so sadly!

Fences grin at You with their teeth of rotten rails

And fire green spit - leafy green of oaks. -

Until a policeman at a junction tangles you with his baton

Into a stream of carts, into nodes created by cars.

In the history of your pain, cutting with hours' teeth,

As if with a lost shoe you leave your youth on the cobbles.

Only when dusk sprays your starry golden oats,

You return tired to the stable to rest in soft straw.

Listening restlessly on to strews singing, an old memory...

Of meadows you dream, sweet and green. - you reminisce old events...

When the night finally covers your eyes with darkness like a mare with her crest,

You feel a young colt in the green cradle of a pasture.

${ }^{37}$ G. Timofiejew, O koniu, który tęskni, “Czasopismo Poetyckie Meteor” 1928, issue 2, p. 24. 
Here, the poet used an essentially suggestive comparison between a labourer and a horse. The rhythm of the life of a man working at a factory is governed by commands and bans established by the aristocrat, and the observance of those rules is enforced by the policeman ${ }^{38}$. The miserably paid labourer, just like the domesticated animal, is a necessary tool in the hands of their master - one that is used for multiplying the fortunes of the factory owners' families:

W kole twojego cierpienia, tnącem zębami godzin,

jak zgubioną podkowę zostawiasz na bruku młodość.

Dopiero gdy zmierzch ci posypie gwiazd pozłocisty owies, wracasz zmęczony do stajni spocząć na miękkiej słomie.
In the circle of your pain, cutting with hours' teeth,

Like a lost shoe you leave your youth on the cobbles.

Only when dusk sprays your starry golden oats,

you return tired to the stable to rest in soft straw.

The man has been deprived of his "coltish" joy and waywardness, and instead became a trusted servant of the local capitalist locked in a Eódź factory.

In texts which discussed the problems of labourers, Meteors consistently argued that the thick factory walls were not the appropriate place for human beings - they could be compared to a dungeon in which proletarians were exploited; they only returned home by dint of the so-called "passes" once they finished work, only to regain their power for the next day of the grind.

\section{Revolutionary reflections in the texts by the Meteor's poets}

In the minds of natives and visitors, the old Łódź appears only as an industrial centre dynamically developing from the mid-19th century, the traces of which can easily be found, e.g. by studying the city's architecture filled with factory complexes and manors of their owners. When considering the city's history, people very rarely recall the year 1905 and the Łódź Insurrection, also referred to as the "June Days". On 22nd June, an insurrection broke out on Wschodnia St.; it was fuelled by numerous strikes and lasted until 1907. In none of their poems did the poets affiliated with Czasopismo Poetyckie Meteor clearly indicate who fought to eliminate the exploitation of labourers by Łódź factory owners. Yet in some works, e.g. in the already mentioned Pajak fabryczny, authors clearly referred to one proletariat postulate, i.e. an eight-hour workday. The demand was commented upon by Emil Noinski, the reviewer of the article titled Dziedzictwo rewolucji 1905-1907 roku:

The events of the 1905-1907 insurrection have stirred much controversy among historians for many years now. In the PRL's [People's Republic of

\footnotetext{
${ }^{38}$ The policeman in the poem, as in Aleksander Wat's early poems - mainly in the poem Policjant - is depicted as a guard of "safety" and is a symbol of social oppression and the marginalisation of the working class. The "policeman with a bulldog's eye" is God, who enforces order which he himself established. The reality in which revolutionaries live resembles a prison cell.
} 
Poland] historiography it was presented extremely single-sidedly with the emphasis put on the issues of the worker movement. Thus, a false image of those years were created which clearly glorified the participation of only one political camp in the insurrection, while in fact its main driving force was a universal protest in which side by side workers there also participated peasants and pupils fighting for Polish to be used at schools. Therefore, the revolution far exceeded the framework of "proletariat" rallies. ${ }^{39}$

The question of the insurrection was raised by Stefan Flukowski ${ }^{40}$ in the poem titled Rewolucja ${ }^{41}$ :

Żołnierze u gwiazd wiszą jak na szubienicy -

gwiazdy na czarnych sznurach zwisły u księżyca -

czerep rogaty wlecze małych gwiazd miljony -

i nurzą je jak koty w spiralnej mgławicy -

wodzowie po ścieżkach polnych szukają rumianków -

i ciągną jak kościelni za sznur lila dzwonki -

spragnieni piją resztę wody w potłuczonym dzbanku -

ich sławę dzwonią wbite $\mathrm{w}$ niebo pierzaste skowronki.

Z żądłami zębatemi ku słońcu podbiegły

pszczoły z ulów, po trawie próchnicą sypiących. -

mrówki czarne zajadle, urodzone w dębach,

i szarańczy żółty tuman błyszczący -

Wczoraj dźwignęły pszczoły na skrzydłach ul własny
Soldiers up with stars hang in the gallows -

stars on black lines hang from the Moon -

a horned head draws millions of small stars -

and wallow them like cats in a spiral nebula -

leaders seek camomile in field paths -

and they drag like sextons draw bell lines -

the thirsty drink the last of water from a broken pitcher -

fluffy larks thrust into the sky sing their fame.

With their toothed stings there came towards the sun bees from hives, spreading decay on the grass. -

black ants fiercely, born in oaks, and the glistening yellow cloud of locust -

Yesterday bees lifted their own hive on their wings

39 E. Noiński, Dziedzictwo rewolucji 1905-1907, eds. A. Żarnowska, A. Kołodziejczyk, A. Stawarz, P. Tusiński, [review], “Niepodległość i Pamięć” 2010, no. 17/1 (31), pp. 375-377.

${ }^{40}$ (1902-1972) - a Polish writer and poet affiliated with the Kwadryga literary group, one of the first and most important representatives of surrealism in Poland. Flukowski's poetry expressed the apotheosis of work as the basic value of the world. A recurring motif in his works was the image of everyday people's work perceived as the completion of God's act of creation. Stefan Flukowski, in: Wspótcześni polscy pisarze..., eds. J. Czachowska, A. Szałagan, Warsaw 1994, vol. 2, pp. 325-328.

41 S. Flukowski, Rewolucja, “Czasopismo Poetyckie Meteor" 1928, issue 3, p. 66. 
i rzuciły pod jabłoń, jabłkami nabitą -

mrówki nogami kopiec po lesie rozniosły -

szarańcza cisnęła w dół sklep nieba, mrokiem kryty.

Senne szczury na trupach płyną mętem rzeki -

Nie myślą, nie czekają ranka, co zaświeci:

Wyjdą z wody na brzegi: będą szukać domów

Rozsiadłych w piaskach sypkich pod lasem dalekim.

Pękną miedziane chmury - grad szarańczę zasiecze -

Mrówki zniosą pod korą białe, okrągłe jaja -

Kulawy dziad ul kryty blachą w sadzie ustawia -

Nad ziemią błękitne niebo smugami się wlecze. and thrust it under the apple tree, filled with apples -

the ants spread the hill through the forest on their feet -

the locust thrust down the sky, covered with darkness.

Drowsy rats flow down the river on corpses -

They do not think, they do not wait till morning to come:

They will emerge from the water onto the shore: they will seek out homes

Spread in loose sands by the nearby forest.

The copper clouds will break - hail will kill the locust -

The ants will lay underneath bark white round eggs -

A limping duffer will put a hive with a metal roof in the orchard -

Blue sky drags in streaks above the ground.

The author metaphorically transferred (as suggested by constructive metaphorism) the field of insurrection battles into a meadow which is the stage of the fierce battle between bees and ants, the disguise of which the poet used in order to convey labourers oppressed by the crazed locust, i.e. the tzar, represented by the army and the police. Already in the first stanza, the poetic persona presumes that the memory of the insurrection fights from 1905-1907 will not survive the trials of time: "fluffy larks thrust into the sky sing their fame." The concept of placing the revolutionary activities in a completely different reality and presenting the insurgents as an insect colony provides grounds for discussing the importance of the uprising and its significance in the minds of Poles. This can be inferred from the following lines:

Wczoraj dźwignęły pszczoły na skrzydłach ul własny

i rzuciły pod jabłoń, jabłkami nabitą -

mrówki nogami kopiec po lesie rozniosły -

szarańcza cisnęła w dół sklep nieba, mrokiem kryty.
Yesterday bees lifted their own hive on their wings

and thrust it under the apple tree, filled with apples -

the ants spread the hill through the forest on their feet -

the locust thrust down the sky, covered with darkness. 
From that pessimism-riddled image of the Łódź Insurrection depicted by the author, some minor rays of light "emerge" timidly while the "blue sky drags in streaks above the ground."

A similarly interesting metaphor of the insurgents fighting in Łódź was used by Stefan Flukowski in the poem titled Śmierć na Mount Evereście ${ }^{42}$ :

Prą Irvinie i Mallory! Woli twarde kleszcze

sprężyły zwoje mięśni i ścisnęły gardła,

więc orząc dzicz żywiołów, jak uparte radła,

naprzełaj odwalają złą, spiętrzoną przestrzeń.

Prą pod włos prują grzywy chłoszczącej wichury, co żagle ciał zamiata, napięte na linach, i w burzy wrzących śnieżyc, krwawo walcząc, płyną po płaszczyznach, opartych o przepaść chmury.

Aż przeprą zbałwanionych śnieżyc oceany,

tabuny skał skaczących z wichrami na karkach,

i staną: na szczycie, płynącym w chmur falach, jak barka, wiecznym wiatrem jak flagi łomotem miotani.

A wtedy węzły mięśni rozwiążą się miękko:

już dalej iść nie można - już wszystko się stało -

teraz mózgi naleje krew wolno i biało

i marzenia popłyną ociężałą rzeką.
Irvine and Mallory push on! The will's hard claws

flexed muscles and gripped throats, so ploughing savagery of elements, like stubborn listers, thrust aside the bad heaped space.

They push against the grain they rip the feather of the slashing storm,

which sweeps body sails, tense on lines,

and in the storm of boiling snow, fighting bloodily, they flow over the surfaces, resting against the void of clouds.

Until they push through the oceans of feathered snowstorms, crowds of rock jumping with wind blows in necks,

and they stand: on the top, flowing in the waves of clouds, like a barge,

thrust with the rumble of eternal wind like flags.

And then the knots of muscles will untie softly:

there is nowhere more to go - all is done -

now brains will fill with blood slow and white

and dreams will flow in a heavy river. p. 67.

42 S. Flukowski, Śmierć na Mount Evereście, "Czasopismo Poetyckie Meteor" 1928, issue 3, 
Zamknięte lodem powiek stawy oczu widzą:

odbija się w nich większy szczyt, większy bez granic!

tam pójdą! Tam ku niemej, otwartej otchłani

i nagle - runą z nieba czarną błyskawicą...

Na białej karcie śniegu, gdzie nic się nie dzieje,

czarną kropką ciał martwych skończą epopeę...
Closed shut with ice on eyelids, the ponds of eyes see:

they reflect a taller peak, bigger without limits!

there they will go! There, towards the silent open void

and suddenly - they will fall from the sky in a black lightning...

On the white sheet of snow where nothing happens,

they will conclude the epic poem with a black dot of dead bodies...

The bloody events from the insurrection were compared to the expedition to Mount Everest, the tallest peak in the world. The poet began the poem by encouraging the insurgents to fight, to fend off the enemy, i.e. the "heaped space." To that end, he referenced in the first words the figures of two legendary mountaineers: George Herbert Leigh Mallory ${ }^{43}$ and Andrew Irvine ${ }^{44}$, who in 1924 tried to summit Mount Everest, which ended tragically. Even though the expedition ended in the deaths of both climbers, their achievement became historic. A similar course of events applied to the ferocious fight of the insurgents. Stefan Flukowski described the struggles of the proletariat after drawing inspiration from his observations of atmospheric phenomena in the mountains. He included in sequence: winds, snowstorms, clouds. Depending on their intensity, they symbolised attacks of the enemies on the insurgents, who died in glory in the fervent of the fight, leaving a faint trace: "On the white sheet of snow where nothing happens,/ they will conclude the epic poem with a black dot of dead bodies." 45

Apart from discussing the dramatic outcomes of the insurrection in the short poem titled Zdarzenie ${ }^{46}$, Grzegorz Timofiejew - the main theoretician of Meteors - also referred to the degradation of a human being as an individual who became part of a mass:

${ }^{43}$ (1886-1924) - one of the greatest mountaineers of the interwar period, the only member of all three British expeditions to Mount Everest in 1921-1924. A history teacher by trade, he worked in the Charterhouse (until 1921, with a gap during the First World War) C. Ankers, D. Roberts, Zaginiony. Rzecz o odnalezieniu Mallory'ego na Evereście, Warsaw 2012, pp. 15-17.

44 (1902-1924) - a British mountaineer; he participated in the 1924 British expedition to Mount Everest. During the first attempt to summit Mount Everest, he and George Mallory, his climbing partner, vanished on the north-east ridge. They were last seen only a few hundred metres from the peak. Mallory's body was recovered in 1999; Irvine's body has not been found to date. Vide: ibid., p. 17.

45 S. Flukowski, ibid.

46 G. Timofiejew, Zdarzenie, “Czasopismo Poetyckie Meteor” 1928, issue 3, p. 61. 
Ktoś się nagiął, ktoś się pochylił,

Ktoś ciało jak gałązkę pod ciało kół kładł.

Trzasnęło! - - - - - Potem

Była cisza pożółkła - - - - - - - -

W ciche, żółknące dale

Ktoś, westchnąwszy, bezszumnie odszedł.

(A gdy szedł, wieczór krwią zaplamił

I zgubił imię najsłodsze).
Someone bent, someone inclined,

Someone put their body as

a branch under the body of wheels.

It snapped! - - - - - Then

There was yellowed silence

Into quiet, yellowing distances

Someone, having sighed, left

buzzlessly.

(And as he went, he stained the evening with blood

And lost the sweetest name).

The author raised the important issue of fate awaiting a labourer as an individual, not like it had been done in previous texts by poets who published in the Meteor poetic periodical, where a labourer was part of a mass of the fighting proletariat. No one can identify the fighters, one amongst them is referred to in the poem as "someone" who "having sighed, left buzzlessly".

\section{Conclusion}

The artistic activities of the Meteor group showed a minor presence in the literary community. The only surviving proof of its existence, apart from references in the biographies of its representatives, includes merely three issues of Czasopismo Poetyckie Meteor as well as scattered texts in Dodatek Literacki and in several issues of Głos Polski. As a result, the Meteor group could be considered as being ephemeral. (After 1945, many groups of such focus operated in Łódź, e.g. 'Statyzm' or 'Metro', established by Henryk Zasławski ${ }^{47}$ ). The lack of interest in the achievements of the group resulted mainly from the lack of literary aficionados among the inhabitants of Łódź. Even though the members of the group raised regional topics, e.g. the events of the 1905 Insurrection, the June Days, and the despicable working conditions in the factories within the cityscape, the poets did not gain any major popularity. Yet, their achievements were significant enough to constitute a reason for considering 'Meteor' as the first Łódź-based literary group. Importantly, however, Meteors did not prove original enough to stand out among proletariat poets or those poets who emulated the Awangarda Krakowska group.

47 Born in 1948 - an employee of the Youth Culture Centre, the founder of the 'Centauro' literary group. He débuted in 1970 in the Literary Almanac of the Distance Club of Young Writers under the pseudonym Kamil Przybylski. Vide Henryk Zasławski [in:] Współczesna Łódź literacka. Słownik Autorów, ed. T. Błażejewski, Łódź 1989, p. 132. 


\section{REFERENCES}

Ankers C., Roberts D., Zaginiony. Rzecz o odnalezieniu Mallory'ego na Evereście, Warsaw 2012.

Barański Z., Rosyjska literatura radziecka, [in:] Dzieje literatur europejskich, vol. 3, Warsaw 1989.

Broniewski W., Stande S.R., Wandurski W., Trzy salwy: biuletyn poetycki, Warsaw 1925.

Cieślak T., Bóg i niebo w poezji rewolucyjnej dwudziestolecia międzywojennego, "Acta Universitatis Lodziensis. Folia Litteraria Polonica" 2001, no. 4, Łódź.

Czasopismo Poetyckie Meteor, issue 1, Warsaw 1928.

Czasopismo Poetyckie Meteor, issue 2, Warsaw 1928.

Czasopismo Poetyckie Meteor, issue 3, Warsaw 1928.

Literaria Humanitas, Brno 2003.

Makowiecki A.Z., Kultura Robotnicza, [in:] Literatura polska, przewodnik encyklopedyczny, vol. 1, Warsaw 1984.

Noiński E., Dziedzictwo rewolucji 1905-1907, eds. A. Żarnowska, A. Kołodziejczyk, A. Stawarz, P. Tusiński, [review], “Niepodległość i Pamięć” 2010, no. 17/1 (31).

Pleszkun-Olejniczakowa E., Kulturowy rozwój Łodzi, “Acta Universitatis Lodziensis. Folia Litteraria Polonica" 2015, issue 3.

Stolarzewicz L., Literatura Łodzi w ciagu jej istnienia. Szkic literacki i antologia, Łódź [no publisher information].

Wat A., Poezje zebrane, Warsaw 1992.

Wspótczesna Łódź literacka. Słownik Autorów, ed. T. Błażejewski, Łódź 1989.

Wspótcześni polscy pisarze i badacze literatury. Stownik Bibliograficzny, eds. J. Czachowska, A. Szałagan, Warsaw 1994, vol. 1.

Wspótcześni polscy pisarze i badacze literatury. Stownik Bibliograficzny, eds. J. Czachowska, A. Szałagan, Warsaw 1994, vol. 2.

Wspótcześni polscy pisarze i badacze literatury. Stownik Bibliograficzny, eds. J. Czachowska, A. Szałagan, Warsaw 1994, vol. 3.

Wspótczésni polscy pisarze i badacze literatury. Stownik Bibliograficzny, eds. J. Czachowska, A. Szałagan, Warsaw 1994, vol. 7.

Wspótcześni polscy pisarze i badacze literatury. Stownik Bibliograficzny, eds. J. Czachowska, A. Szałagan, Warsaw 1994, vol. 9.

http://ipsb.nina.gov.pl

http://www.biblioteka.uznam.net.pl

http://www.encysol.pl

http://www.polonia.kharkov.ua/pl

https://digilib.phil.muni.cz

\section{SUMMARY}

The article is devoted to the first Łódź-based literary group called 'Meteor', which operated in 1928-1930. The author mainly focuses on providing a reliable discussion of the circumstances of the establishing of the group by its founders, i.e. Grzegorz Timofiejew, Marian Piechal, and Kazimierz Sowiński, and a careful specification of 
its programme. She also interpreted the Meteor's works, i.e. revolutionist literary texts published in the Czasopismo Poetyckie Meteor, created by the members of the group.

\section{Keywords}

proletariat poetry, the "Meteor" group, literary group in Lodz, Poetic Journal Meteor

Alicja Krawczyk - graduate of Polish Studies, Faculty of Philology, University of Lodz; currently a doctoral candidate at the Department of Literature and Tradition of Romanticism, University of Lodz. Her main focus is the study of the region's literature written in the 20th century, particularly of the history of literary life in reference to the activities of Łódź-based literary groups or the operations of literary cafés. She is the author of Łódzkie kawiarnie literackie w II połowie XX wieku, which was published in "Przegląd Humanistyczny" 4/2019.

e-mail: alakrawczyk3@gmail.com 